\title{
Intraoperative damage to surgical gloves during various operations on the musculoskeletal system: a multicenter study
}

\author{
Andreas Enz ${ }^{1} \mathbb{D} \cdot$ Tanja Kostuj $^{2} \cdot$ Philipp Warnke $^{3} \cdot$ Katrin Osmanski-Zenk $^{1} \cdot$ Wolfram Mittelmeier $^{1} \cdot$ Annett Klinder $^{1}$
}

Received: 7 July 2020 / Accepted: 16 August 2020 / Published online: 29 August 2020

(C) The Author(s) 2020

\begin{abstract}
Introduction Various orthopedic surgical procedures cause mechanical stress for gloves. In some cases, sharp-edged objects impact on the glove surfaces. The systematic description of lesions is still missing.

Methods 2289 gloves from 409 surgeries [primary hip and knee arthroplasties (PA), revisions arthroplasties (RA) and arthroscopic shoulder, hip and knee surgery (AY)] from 3 clinics were examined for lesions using water tightening test according to the European norm EN 455-1.

Results Arthroscopies showed the lowest rate of operations with damaged gloves (6.9\%). Depending on clinic, 32.7\% and $59.2 \%$ of PA surgeries generated damaged gloves, while in RA, these numbers rose to $76.0 \%$ and $72.8 \%$, respectively. In PA and RA, the most affected finger was the index finger, whereas in arthroscopies, more damage occurred on the middle finger and the thumb. The size of the lesions was rather small with the vast majority being $1 \mathrm{~mm}$ or $2 \mathrm{~mm}$ in size.

Conclusion All investigated interventions led to glove lesions. With increasing mechanical stress, the number of glove defects increased. EN 455 does not account for the intraoperative tear risk. Stricter requirements for gloves should be introduced. Glove change intervals should be defined and implemented, and new materials should be developed.
\end{abstract}

Keywords EN 455-1 · Damage $\cdot$ Orthopedic surgery $\cdot$ Surgical side infection $\cdot$ Glove $\cdot$ Lesions

\section{Introduction}

Surgical gloves with their thin layer of latex are the only mechanical barrier between the patient and the operating team and are intended, apart from various (constructional-) technical requirements in an operating theatre, to protect both sides against infection [1,2]. The sterile latex surgical glove is used in a variety of disciplines, for example in gastroscopy, cardiac catheter interventions or in invasive and minimally invasive orthopedic and traumatological procedures [3, 4]. According to the European Committee for Standardization (CEN) standard EN 455, the gloves produced are randomly tested for waterproofness (EN 455-1)

Andreas Enz

andreas.enz@med.uni-rostock.de

1 Orthopädische Klinik und Poliklinik, Universitätsmedizin Rostock, Rostock, Germany

2 Orthopädisch-Traumatologisches Zentrum, St. Marien-Hospital Hamm, Hamm, Germany

3 Institut für Medizinische Mikrobiologie, Virologie und Hygiene, Universitätsmedizin Rostock, Rostock, Germany by means of a water tightening test (1L water for 2-3 min) and tear resistance (EN 455-2) with a maximum weight of $9 \mathrm{~N}$ as standard. The defined acceptable quality limit (AQL) for surgical gloves was 1.5 , which means that for 50 tested latex gloves, 2 gloves may be damaged without the production batch having to be discarded [5]. In the draft standard (preEN 455-1:2019), the AQL has been adjusted to 0.65 [6] and was adopted in the new version EN 455-1:2020 [7]. Nevertheless, the currently valid standard is significantly less stringent as compared to the testing of other latex products, such as for example condoms (AQL 0.25) [8]. Mechanical loads such as shear force, repetitive movements and sharpedged surfaces are not taken into consideration when testing surgical gloves [5]. No specifications regarding minimum thickness, tensile strength and elongation at break are given. The aim of this study was to investigate whether operations with different mechanical stress have an influence on the frequency and type of perforation. A total of 2289 gloves were tested and evaluated by means of a water tightening test (EN 455-1) after primary and revision endoprosthetics on knee and hip, as well as after arthroscopic surgery. 


\section{Method}

\section{Clinics and operations}

At the Clinic for Orthopedics and Trauma Surgery, Catholic Hospital Bochum, University Hospital of the Ruhr-University Bochum and the Clinic for Orthopedics and Trauma Surgery Clinic Lippe in Lemgo (BuL) surgical gloves from primary hip and knee endoprostheses as well as hip and knee revision arthroplasties were examined and compared to the data of the Orthopedic Clinic and Policlinic of the University Medical Center Rostock (UMR) which were collected from primary hip and knee arthroplasties, hip and knee revision arthroplasties. Additionally, gloves retrieved from arthroscopies (hip, knee and shoulders), were collected at UMR.

\section{Gloves}

From July 2016 until October 2019, 827 surgical gloves were collected at the Clinic for Orthopedics and Trauma Surgery, Catholic Hospital Bochum, University Hospital of the Ruhr-University Bochum and the Clinic for Orthopedics and Trauma Surgery Clinic Lippe in Lemgo (BuL) and subsequently compared to an existing database from the Orthopedic Clinic and Policlinic of the Rostock University Medical Center about glove damage whose data were partly reported previously [9, 10]. In total, 2289 surgical gloves from 409 surgeries, including 153 primary endoprostheses implantations, 155 revision arthroplasties and 101 arthroscopic interventions, were examined. The number of gloves used, number of gloves per operation, type of operation (knee, hip or shoulder), duration of the operation, type of surgeon (according to Endocert certification) and the use of bone cement or the removal of bone cement were documented. All operations were performed with two pairs of gloves in the so-called double-gloving procedure. Sterile, powder-free latex gloves for single use (ProtexisTM, Cardinal Health, Dublin, Ohio, USA (AQL 0.65); Vasco ${ }^{\circledR}$ OP eco, B.Braun, Melsungen, Germany (AQL 0.65); Neolon ${ }^{\circledR} 2 \mathrm{G}$ surgical gloves, Medline Industries, Inc, Northfield, USA (AQL
0.65); Biogel Eclipse, Mölnlycke Health Care, Gothenburg, Sweden (AQL 0.65) and Sempermed supreme, Sempermed/ Semperit, Vienna, Austria (AQL 0.65) were investigated.

\section{Method of investigation}

Gloves from endoprosthetic interventions were changed intraoperatively as a routine procedure before implantation of the endoprosthesis parts, contact with cement, in the case of obvious damage and after $2 \mathrm{~h}$ (for more details, see Text box A). The gloves of the leading surgeon were collected and packed for each individual operation and the data relevant for evaluation were documented. For operations without change of gloves (arthroscopies), the gloves were collected after finishing the operation. The examination was carried out in the UMR laboratory. Gloves from BuL were packed separately for each operation, free of pressure points and sent to Rostock for evaluation. As control, the influence of glove undressing was tested on 50 gloves without surgery. 50 gloves without surgery were tested after postage (3 days duration). The evaluation was performed according to EN 455-Medical gloves for single use part 1, method for testing for freedom from holes with water tightening test $[5,10]$. The localization of the damage was determined, size and dimension were measured with a plastic goniometer (Kirchner \& Wilhelm GmbH \& Co. KG, Asperg, Germany) and the lesion configuration was recorded with microscopes (Laser Scanning Microscope VK-S1100 and Digital Microscope VHX-6000, Keyence, Germany).

\section{Statistics}

The collected data were analyzed using SPSS Statistics Package Version 22 (IBM Corp., New York, USA). Descriptive statistics were calculated for continuous and categorical variables. Continuous variables are displayed as mean values and standard deviations (SD) as well as median and range as most of the data were not normally distributed. Categorical factors are shown as frequency $(n)$ with percentages in brackets. Testing for differences of categorical factors between different types of operations was done by the
Text box A Intraoperative glove change algorithm

\begin{tabular}{|c|c|c|c|}
\hline Operation & Glove change & & \\
\hline Primary arthroplasty & implantation cup & $\begin{array}{l}\text { Implantation stem/ } \\
\text { components }\end{array}$ & $\begin{array}{l}\text { Obvious damage, } \\
\text { cement contact, } \\
\text { after } 2 \text { h sur- } \\
\text { gery }\end{array}$ \\
\hline Revision arthroplasty & After mechanical stress & $\begin{array}{l}\text { Implantation of the } \\
\text { definitive implants }\end{array}$ & $\begin{array}{l}\text { Obvious damage, } \\
\text { cement contact, } \\
\text { after } 2 \text { h sur- } \\
\text { gery }\end{array}$ \\
\hline Arthroscopy & Duration over $1 \mathrm{~h}$ & & Obvious damages \\
\hline
\end{tabular}


exact Fisher test (two categories) or by Pearson's chi-square test (more than two categories). Testing for differences in continuous variables between different types of operations was performed using Kruskal-Wallis test. The significance level was set at $p<0.05$.

\section{Ethics vote and data privacy}

Ethics approval for the study was granted by the local ethics committee of the Rostock University Medical Center (registration number: A2016-0112) and data protection requirements were observed.

\section{Results}

\section{General patient data and surgical method}

The demographic data of the 409 participating patients are listed in Table 1. A total of 2289 surgical gloves were collected, 540 gloves from 104 primary arthroplasty operations, 669 gloves from 100 revision arthroplasty operations and 251 gloves from 101 arthroscopy interventions. A total of 827 gloves from the clinics in Bochum and Lemgo were analyzed, 346 gloves were used in 49 primary endoprostheses and 481 in 55 revision operations, of which 226 were inner gloves and 601 were outer gloves.

\section{Comparison of intraoperative lesions}

Table 2 shows the comparison of the three types of surgery, PA, RA and AY, as well as the damage on the other centers (cumulative). While gloves were damaged the least (6.9\%) in $\mathrm{AY}$, the number of operations with glove damage increased to $32.7 \%$ in PA-UMR and $59.2 \%$ in PA-BuL. In RA-BuL, $72.7 \%$ and RA-UMR $76.0 \%$ of the surgeries were found to have damaged gloves. While the overall percentage of damaged gloves in PA and RA ranged from 10.9 to $25.0 \%$ in both centers, a detailed analysis of the gloves collected in the BuL clinics showed that inner gloves were with $6.2 \%$ less damaged than outer gloves (19.0\% damaged/total number of gloves).

\section{Gloves and operating time}

The highest number of gloves per surgery was spent in RA, the intervention with the longest duration of surgery (Table 2). The correlation between number of damaged gloves and duration of surgery was significant in RA (BuL $r=0.363, p=0.007$; UMR $r=0.208, p=0.037$ ), but not in primary endoprosthetics (BuL $r=0.087 p=0.553$, UMR $\mathrm{r}=0.093 p=0.346$ ). The use of bone cement for fixation of the implant in PA and RA had no influence on the number of damaged gloves in the center of Rostock. In contrast, cement removal in BuL showed a significant influence on the lesion rate of the gloves $(p=0.026)$ in RA. Overall, there was a correlation in the damage rate between operations with and without cement removal $(p=0.054)$, but not between uncemented and cemented implants $(p=0.488)$.

\section{Location and size of the glove lesions}

Significant differences in the position of glove damage were found for the different types of surgery. The lesion rate for PA on the index finger and index fingertip was $61.1 \%$ (UMR) and $50.7 \%(\mathrm{BuL})$, for RA $43.0 \%(\mathrm{UMR})$ and $47.5 \%(\mathrm{BuL})$. In AY, thumbs were affected in $33.3 \%$ and middle fingers in $55.0 \%$ of cases. In gloves used at the UMR, the damage in PA was in the area of the dominant hand (61.0\%), in RA rather in the area of the subordinate hand (59.6\%). Gloves from operations at BuL displayed glove damage more frequently in the area of the subordinate hand in PA and RA (Fig. 1b, c). For a detailed analysis, see Table 3 and Fig. 1 (b-f). In AY, 66.7\% of the damage was in the area of the subordinate hand, distributed over the thumb (22.2\%), index fingertip (11.1\%), middle finger and middle fingertip $(22.2 \%)$ and tip of the ring finger (11.1\%). The dominant hand showed only a third of the damage, located almost

Table 1 Descriptive analysis of patient demographic data

\begin{tabular}{|c|c|c|c|c|c|}
\hline & \multicolumn{2}{|c|}{ Patients with primary arthroplasty } & \multicolumn{2}{|c|}{ Patients with revision arthroplasty } & \multirow{2}{*}{$\begin{array}{l}\text { Patients with arthroscopy } \\
\text { UMR }\end{array}$} \\
\hline & UMR & $\mathrm{BuL}$ & UMR & $\mathrm{BuL}$ & \\
\hline \multicolumn{6}{|l|}{ Patient data } \\
\hline Number of patients recruited $(n)$ & 104 & 49 & 100 & 55 & 101 \\
\hline Male $[n,(\%)]$ & $49(47.1)$ & $16(32.7)$ & $49(49.0)$ & $24(43.6)$ & $47(46.5)$ \\
\hline Female $[n,(\%)]$ & $55(52.9)$ & $33(67.3)$ & $51(51.0)$ & $31(56.4)$ & $54(53.5)$ \\
\hline $\begin{array}{l}\text { Age in years }[\mathrm{M} \pm \mathrm{SD} \\
\mathrm{MD} \text { (range) }]\end{array}$ & $\begin{array}{l}68.1 \pm 11.4 \\
72(20-84)\end{array}$ & $\begin{array}{l}74.5 \pm 11.9 \\
73(34-98)\end{array}$ & $\begin{array}{l}68.9 \pm 10.4 \\
71.5(22-84)\end{array}$ & $\begin{array}{l}76.7 \pm 10.8 \\
79(47-93)\end{array}$ & $\begin{array}{l}47.6 \pm 16.3 \\
51(12-82)\end{array}$ \\
\hline $\begin{array}{l}\text { Body mass index }[\mathrm{M} \pm \mathrm{SD} \\
\mathrm{MD} \text { (range) }\end{array}$ & $\begin{array}{l}29.9 \pm 5.5 \\
29.3(19.2-49.3)\end{array}$ & $\begin{array}{l}28.4 \pm 5.0 \\
27.9(15.8-39.2)\end{array}$ & $\begin{array}{l}29.2 \pm 5.4 \\
29.0(17.6-44.4)\end{array}$ & $\begin{array}{l}28.94 \pm 5.8 \\
28.1(20.8-50.7)\end{array}$ & $\begin{array}{l}27.9 \pm 4.9 \\
27.1(16.8-42.8)\end{array}$ \\
\hline
\end{tabular}


Table 2 Statistical analysis of surgical data with regard to the occurrence of glove damage of the entire surgery

\begin{tabular}{|c|c|c|c|c|c|c|}
\hline & \multicolumn{2}{|c|}{ Primary arthroplasty } & \multicolumn{2}{|c|}{ Revision arthroplasty } & \multirow{2}{*}{$\begin{array}{l}\text { Arthroscopy } \\
\text { UMR }\end{array}$} & \multirow[t]{2}{*}{$p$ value ${ }^{*}$} \\
\hline & UMR & $\mathrm{BuL}$ & UMR & $\mathrm{BuL}$ & & \\
\hline \multicolumn{7}{|l|}{ OP-specific data } \\
\hline Total number of gloves used $(n)$ & 542 & 346 & 669 & 481 & 251 & 2.289 overall \\
\hline \multicolumn{7}{|l|}{ Number of surgical gloves } \\
\hline Undamaged $[n,(\%)]$ & $483(89.1)$ & $300(86.7)$ & $502(75.0)$ & $399(83.0)$ & $244(97.2)$ & $<0.0001^{+}$ \\
\hline Damaged $[n,(\%)]$ & $59(10.9)^{\mathrm{a}, \mathrm{b}, \mathrm{c}}$ & $46(13.3)^{\mathrm{a}, \mathrm{b}, \mathrm{c}}$ & $167(25.0)^{\mathrm{b}}$ & $82(17.0)^{\mathrm{a}, \mathrm{b}}$ & $7(2.8)^{\mathrm{c}}$ & \\
\hline \multicolumn{7}{|l|}{ Number of operations } \\
\hline Without damaged gloves $[n,(\%)]$ & $70(67.3)$ & $20(40.8)$ & $23(23.0)$ & $15(27.3)$ & $94(93.1)$ & $<0.0001^{+}$ \\
\hline With damaged gloves $[n,(\%)]$ & $34(32.7)^{\mathrm{a}}$ & $29(59.2)^{\mathrm{b}}$ & $77(77.0)^{\mathrm{b}}$ & $40(72.7)^{\mathrm{b}}$ & $7(6.9)^{\mathrm{c}}$ & \\
\hline $\begin{array}{l}\text { Average number of damaged gloves per surgery } \\
{[\mathrm{M} \pm \mathrm{SD} ; \mathrm{MD} \text { (range)] }}\end{array}$ & $\begin{array}{l}5.2 \pm 2.1 \\
4(2-12)^{\mathrm{a}}\end{array}$ & $\begin{array}{l}7.1 \pm 2.4 \\
6(4-16)^{\mathrm{b}}\end{array}$ & $\begin{array}{l}6.7 \pm 3.0 \\
6(2-14)^{b}\end{array}$ & $\begin{array}{l}8.7 \pm 4.5 \\
8(4-28)^{b}\end{array}$ & $\begin{array}{l}2.5 \pm 0.9 \\
2(2-4)^{c}\end{array}$ & $<0.0001^{\wedge}$ \\
\hline $\begin{array}{l}\text { Average number of damaged gloves per surgery } \\
{[\mathrm{M} \pm \mathrm{SD} ; \mathrm{MD} \text { (range)] }}\end{array}$ & $\begin{array}{l}06 \pm 0.9 \\
0(0-3)^{\mathrm{a}}\end{array}$ & $\begin{array}{l}0.9 \pm 1.0 \\
1(0-3)^{\mathrm{a}, \mathrm{b}}\end{array}$ & $\begin{array}{l}1.7 \pm 1.6 \\
1(0-8)^{\mathrm{b}}\end{array}$ & $\begin{array}{l}1.5 \pm 1.4 \\
1(0-7)^{\mathrm{b}}\end{array}$ & $\begin{array}{l}0.1 \pm 0.3 \\
0(0-2)^{c}\end{array}$ & $<0.0001^{\wedge}$ \\
\hline \multicolumn{7}{|l|}{ Operated joint } \\
\hline Shoulder $[n,(\%)]$ & - & & - & & $20(19.8)$ & \\
\hline $\operatorname{Hip}[n,(\%)]$ & $77(74.1)^{\mathrm{a}}$ & $31(63.3)^{\mathrm{a}, \mathrm{b}}$ & $74(74.0)^{\mathrm{a}}$ & $27(49.1)^{\mathrm{b}}$ & $6(5.9)^{\mathrm{c}}$ & \\
\hline Knee $[n,(\%)]$ & $27(25.9)^{\mathrm{a}}$ & $17(34.7)^{\mathrm{a}, \mathrm{b}}$ & $26(26.0)^{\mathrm{a}}$ & $28(50,9)^{\mathrm{b}}$ & $75(74.3)^{\mathrm{c}}$ & $<0.0001^{+}$ \\
\hline Ankle joint $[n,(\%)]$ & & $1(2.0)$ & & & & \\
\hline \multicolumn{7}{|l|}{ Surgery by } \\
\hline Main operator $[n,(\%)]$ & $72(6.2)$ & $45(91.8)$ & $94(94.0)$ & $54(98.2)$ & $84(86.1)$ & $<0.0001^{+}$ \\
\hline Surgeon in training $[n,(\%)]$ & $32(30.8)^{\mathrm{a}}$ & $4(8.2)^{b}$ & $6(6.0)^{\mathrm{b}}$ & $1(1.8)^{\mathrm{b}}$ & $17(13.9)^{\mathrm{a}, \mathrm{b}}$ & \\
\hline \multicolumn{7}{|l|}{ Use of bone cement } \\
\hline Cemented $[n,(\%)]$ & $73(70.2)$ & $21(42.9)$ & $52(52.0)$ & $23(41.8)$ & - & $0.0008^{+}$ \\
\hline Cementless $[n,(\%)]$ & $31(29.8)^{\mathrm{a}}$ & $28(57.1)^{\mathrm{b}}$ & $48(48.0)^{\mathrm{b}}$ & $32(58.2)^{\mathrm{b}}$ & - & \\
\hline \multicolumn{7}{|l|}{ Removal of bone cement } \\
\hline Yes $[n,(\%)]$ & - & - & $49(49.0)$ & $24(43.6)$ & - & 0.6143 \\
\hline No $[n,(\%)]$ & - & - & $51(51.0)$ & $31(56.4)$ & - & \\
\hline $\begin{array}{l}\text { Duration of surgery in min } \\
{[\mathrm{M} \pm \mathrm{SD} ; \mathrm{MD} \text { (range)] }}\end{array}$ & $\begin{array}{l}79.3 \pm 23.3 \\
76(28-140)^{\mathrm{a}}\end{array}$ & $\begin{array}{l}91.6 \pm 25.5 \\
88(52-195)^{a, b}\end{array}$ & $\begin{array}{l}116.8 \pm 48.4 \\
112.5(30-310)^{b}\end{array}$ & $\begin{array}{l}129.7 \pm 62.5 \\
118(23-323)^{b}\end{array}$ & $\begin{array}{l}40.7 \pm 20.5 \\
37(15-112)^{\mathrm{c}}\end{array}$ & $<0.0001^{\wedge}$ \\
\hline
\end{tabular}

${ }^{\wedge}$ Kruskal-Wallis test

${ }^{+}$Chi-square test

'Fisher's exact test for 2 groups

*Total comparison of all 5 groups using Kruskal-Wallis test, Chi-square test or Fisher's exact test

${ }^{\mathrm{a}, \mathrm{b}, \mathrm{c}}$ Groups with different small letters show significant differences $(p<0.05)$, groups with the same small letters do not show significant differences

exclusively in the thumb and middle finger area $(11.1 \%$ and $22.2 \%$, respectively) (Fig. 1d). The dimensions of glove damage ranged from $\leq 1 \mathrm{~mm}$ to more than $5 \mathrm{~mm}$ of size. The size of the lesions in the gloves varied significantly between PA, RA and AY as well as among the centers (Table 3).

\section{Discussion}

In the present study, it was shown that even arthroscopic procedures with little mechanical stress can cause severe damage to the gloves. With increasing mechanical stress, gloves are subject to a higher risk of lesions. It is, therefore, recommended to use the so-called double gloving (DG), i.e. to wear a second pair of gloves on top of the first pair [2]. The literature indicates that the practice of the DG is not practiced uniformly [11], lack of sensitivity in the finger is considered one of the main reasons among surgeons when dispensing with a second pair of gloves (single gloving) [12]. In endoprosthetics, the use of two pairs of gloves is an established standard [13], which is confirmed as necessary by the data of this study and by others $[9,14,15]$. 
0

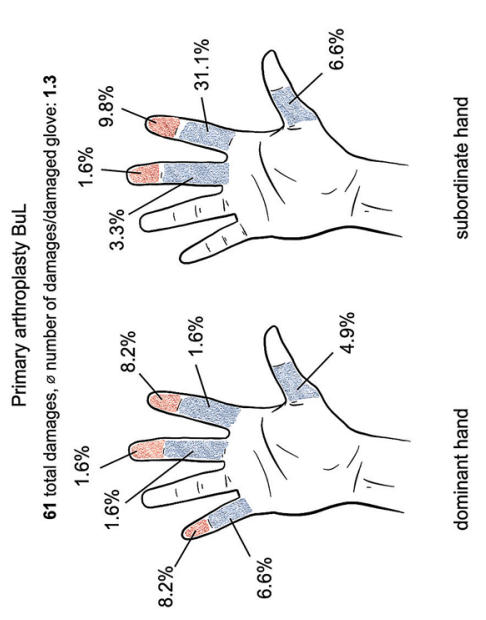

๓

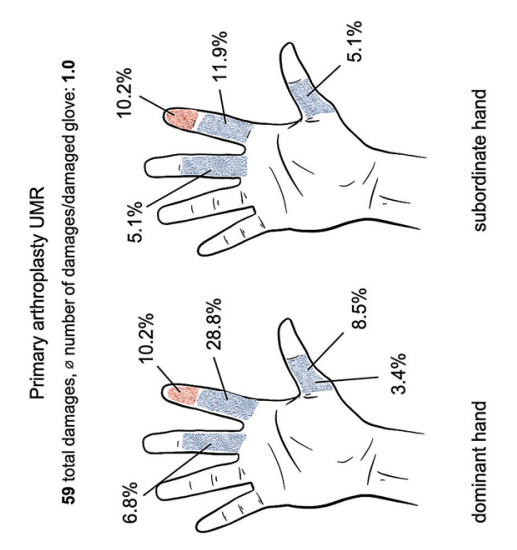

丩

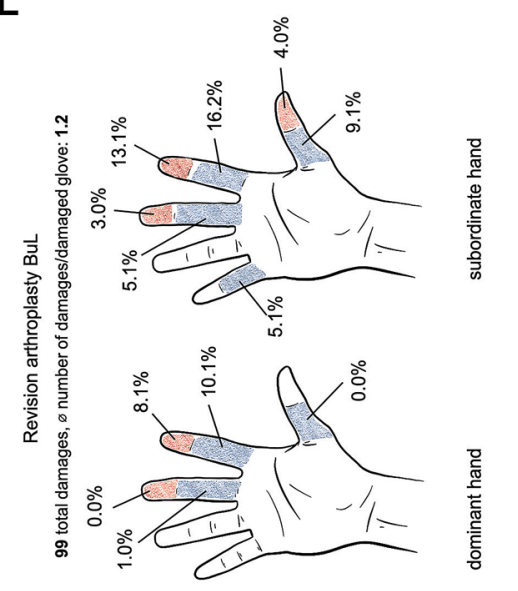

ш

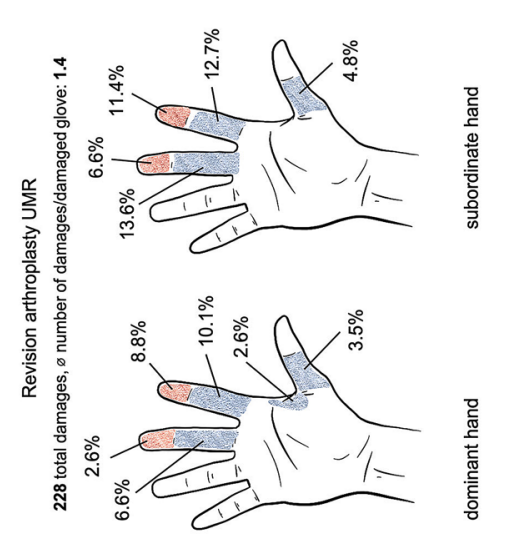

口

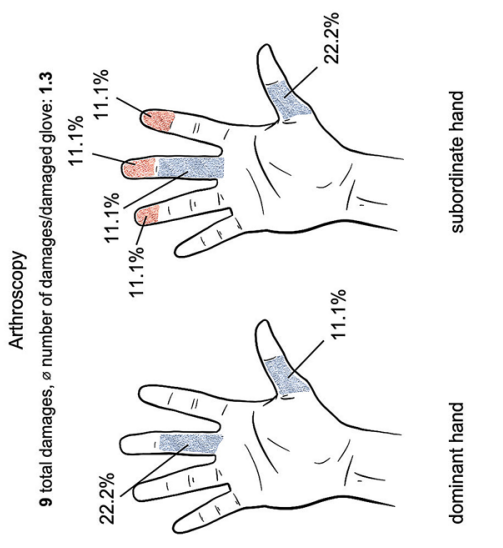

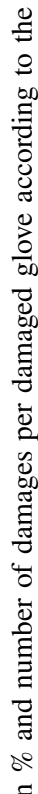

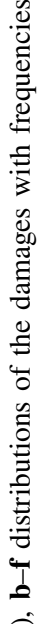

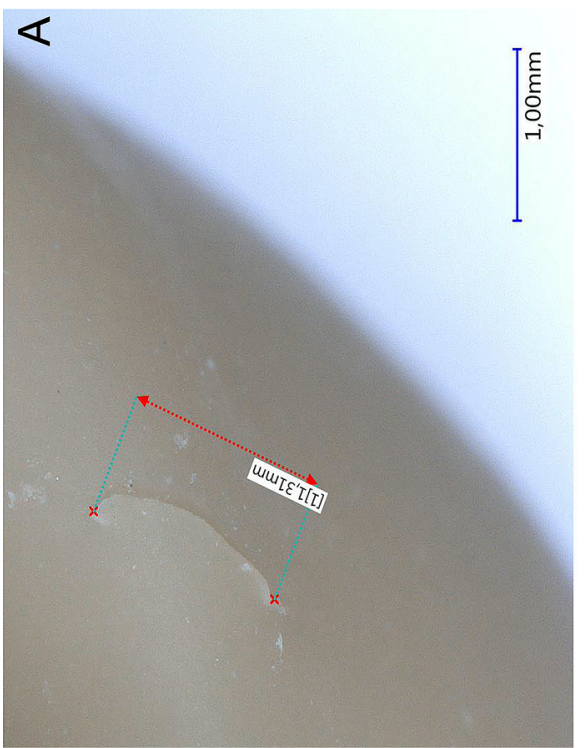


Table 3 Percentage of occurrence of certain (A) localizations and (B) sizes of damage in relation to the total number of damages

\begin{tabular}{|c|c|c|c|c|c|c|c|c|c|c|}
\hline \multirow{5}{*}{$\begin{array}{l}\text { Total number of damages } \\
\emptyset \text { damages/damaged glove }\end{array}$} & \multicolumn{4}{|c|}{ Primary arthroplasty } & \multicolumn{4}{|c|}{ Revision arthroplasty } & \multirow{2}{*}{\multicolumn{2}{|c|}{$\begin{array}{l}\text { Arthroscopy } \\
\text { UMR }\end{array}$}} \\
\hline & \multicolumn{2}{|l|}{ UMR } & \multicolumn{2}{|l|}{$\mathrm{BuL}$} & \multicolumn{2}{|l|}{ UMR } & \multicolumn{2}{|l|}{$\mathrm{BuL}$} & & \\
\hline & \multirow{2}{*}{\multicolumn{2}{|c|}{$\begin{array}{l}59 \\
1.0\end{array}$}} & \multirow{2}{*}{\multicolumn{2}{|c|}{$\begin{array}{l}61^{\mathrm{a}} \\
1.3\end{array}$}} & \multirow{2}{*}{\multicolumn{2}{|c|}{$\begin{array}{l}228^{\mathrm{a}} \\
1.4\end{array}$}} & \multirow{2}{*}{\multicolumn{2}{|c|}{$\begin{array}{l}99^{\mathrm{a}} \\
1.2\end{array}$}} & \multirow{2}{*}{\multicolumn{2}{|c|}{$\begin{array}{l}9^{\mathrm{a}} \\
1.3\end{array}$}} \\
\hline & & & & & & & & & & \\
\hline & $\mathrm{DH}$ & $\mathrm{SH}$ & $\mathrm{DH}$ & $\mathrm{SH}$ & $\mathrm{DH}$ & $\mathrm{SH}$ & $\mathrm{DH}$ & $\mathrm{SH}$ & $\mathrm{DH}$ & $\mathrm{SH}$ \\
\hline \multicolumn{11}{|l|}{ (A) Localizations } \\
\hline Thumbs & 8.5 & 5.1 & 4.9 & 6.6 & 3.5 & 4.8 & 0.0 & 9.1 & 11.1 & 22.2 \\
\hline Thumb tip & 0.0 & 0.0 & 0.0 & 0.0 & 0.9 & 1.8 & 1.0 & 4.0 & 0.0 & 0.0 \\
\hline Thumb/Rasp marks & 3.4 & 0.0 & 0.0 & 0.0 & 0.0 & 0.0 & 0.0 & 0.0 & 0.0 & 0.0 \\
\hline Index finger & 28.8 & 11.9 & 1.6 & 31.1 & 10.1 & 12.7 & 10.1 & 16.2 & 0.0 & 0.0 \\
\hline Index fingertip & 10.2 & 10.2 & 8.2 & 9.8 & 8.8 & 11.4 & 8.1 & 13.1 & 0.0 & 11.1 \\
\hline Middle finger & 6.8 & 5.1 & 1.6 & 1.6 & 6.6 & 13.6 & 1.0 & 5.1 & 22.2 & 11.1 \\
\hline Middle fingertip & 0.0 & 0.0 & 1.6 & 3.3 & 2.6 & 6.6 & 0.0 & 3.0 & 0.0 & 11.1 \\
\hline Ring finger & 0.0 & 0.0 & 0.0 & 1.6 & 0.0 & 1.3 & 1.0 & 2.0 & 0.0 & 0.0 \\
\hline Ring fingertip & 0.0 & 0.0 & 0.0 & 0.0 & 0.0 & 0.0 & 0.0 & 0.0 & 0.0 & 11.1 \\
\hline Little finger & 0.0 & 0.0 & 6.6 & 0.0 & 0.0 & 0.0 & 2.0 & 5.1 & 00 & 0.0 \\
\hline Little fingertip & 0.0 & 0.0 & 8.2 & 0.0 & 0.0 & 0.4 & 0.0 & 1.0 & 0.0 & 0.0 \\
\hline Palm & 1.7 & 3.4 & 6.6 & 1.6 & 3.1 & 2.6 & 3.0 & 3.0 & 0.0 & 0.0 \\
\hline Dors FA/back of the hand & 0.0 & 0.0 & 0.0 & 1.6 & 0.4 & 2.2 & 5.1 & 1.0 & 0.0 & 0.0 \\
\hline Palm FA & 0.0 & 0.0 & 1.6 & 0.0 & 1.8 & 0.4 & 1.0 & 3.0 & 0.0 & 0.0 \\
\hline Between thumb and index finger & 0.0 & 1.7 & 0.0 & 0.0 & 2.6 & 1.8 & 0.0 & 1.0 & 0.0 & 0.0 \\
\hline Index finger/middle finger & 0.0 & 1.7 & 1.6 & 0.0 & 0.0 & 0.0 & 1.0 & 0.0 & 0.0 & 0.0 \\
\hline Between index finger and middle finger & 1.7 & 0.0 & 0.0 & 0.0 & 0.0 & 0.0 & 0.0 & 0.0 & 0.0 & 0.0 \\
\hline Percent per $\mathrm{DH} / \mathrm{SH}$ & 61.0 & 39.0 & 42.6 & 57.4 & 40.4 & 59.6 & 33.3 & 66.7 & 33.3 & 66.7 \\
\hline \multicolumn{11}{|l|}{ Total number of damages $\mathrm{mm}$} \\
\hline \multicolumn{11}{|l|}{ (B) Sizes of damage (mm) } \\
\hline 1 & 5.1 & 6.8 & 23.0 & 37.7 & 8.8 & 23.7 & 11.1 & 39.4 & 11.1 & 44.4 \\
\hline 2 & 22.0 & 13.6 & 8.2 & 11.5 & 12.7 & 18.0 & 12.1 & 14.1 & 11.1 & 11.1 \\
\hline 3 & 15.3 & 10.2 & 3.3 & 0.0 & 5.3 & 6.6 & 2.0 & 8.1 & 11.1 & 0.0 \\
\hline 4 & 13.6 & 5.1 & 0.0 & 3.3 & 3.5 & 4.4 & 4.0 & 1.0 & 0.0 & 11.1 \\
\hline 5 & 1.7 & 3.4 & 3.3 & 3.3 & 1.8 & 3.5 & 2.0 & 2.0 & 0.0 & 0.0 \\
\hline 6 & 1.7 & 0.0 & 0.0 & 1.6 & 3.9 & 1.8 & 0.0 & 0.0 & 0.0 & 0.0 \\
\hline 7 & 0.0 & 0.0 & 1.6 & 0.0 & 0.4 & 0.4 & 0.0 & 0.0 & 0.0 & 0.0 \\
\hline 8 & 0.0 & 0.0 & 1.6 & 0.0 & 0.4 & 0.4 & 0.0 & 0.0 & 0.0 & 0.0 \\
\hline 9 & 0.0 & 0.0 & 0.0 & 0.0 & 0.9 & 0.0 & 0.0 & 0.0 & 0.0 & 0.0 \\
\hline 10 & 0.0 & 0.0 & 0.0 & 0.0 & 1.3 & 0.4 & 0.0 & 1.0 & 0.0 & 0.0 \\
\hline$>10$ & 1.7 & 0.0 & 1.6 & 0.0 & 0.9 & 0.4 & 2.0 & 1.0 & 0.0 & 0.0 \\
\hline
\end{tabular}

Data in \%

DH dominant hand, $S H$ subordinate hand

${ }^{a}$ The total number of damages may differ from the total number of damaged gloves because in some cases several damages per glove were found.

\section{Mechanical stress and operating time}

With increasing mechanical stress, the rate of damage to the material increases, resulting in lesions in the gloves. Harnoss et al. showed in septic laparotomies with low mechanical stress that damage to the glove remains mostly unnoticed and in almost $5 \%$ of cases bacteria can pass through these lesions [16]. It became apparent, that after perforation, bacterial strains were found in the wound infection which were identical to those found on the hand of the performing surgeon [17]. Glove lesions can pose a risk of surgical wound infections. The data of our study prove that, in addition to the mechanical stress, the duration of the operation also has an influence on the number of glove lesions. The number of glove damage increases with the duration of the operation [14], which may result in increased translocation 
of bacteria and thus could be an explanation for the higher infection rates in RA $[18,19]$. Using gloves with indicator system, perforations could be noticed faster and a change of gloves could take place [20]. Definite algorithms for changing gloves even without obvious damage should be established and integrated into the surgical hygiene regulations to reduce infections by microperforation $[15,16]$. The amount of gloves used in RA interventions was significantly higher than in PA and AY, due to the glove change algorithm of the participating clinics (see Text box A). The algorithm takes into account the increased risk of glove damage during mechanically demanding procedures with longer operating times, which is confirmed by the higher number of gloves worn. The literature confirms increased perforation rates in gloves of RA [21].

The use of PMMA bone cement is considered to be a factor for increasing damage rates. Statistically, there was no significant difference in the number of damaged gloves for uncemented and cemented implants, but there was a higher risk of damage when cement was removed during RA.

\section{Location of lesions}

The index finger of the surgeon's dominant and subordinate hand proved to be particularly prone to lesion, especially in RA $[9,10,22]$. This is in line with the findings of other research groups [21, 23]. The shift of lesions from the dominant hand to the subordinate hand in RA, which is present in UMR, can be explained by an increased tactile behavior of the subordinate hand. Different surgical techniques and patient positioning can play a role in this. A comparison of the three endoprosthetic sites showed that there were significant differences in the positions and sizes of the lesions, as well as differences in dominant and subordinate hand. While the number of surgeries in which damage occurred was almost the same for RA in the centers, there was a significant difference in PA-UMR and PA-BuL. With equal qualification and experience of the surgeons at the centers, the variations might be explained by different glove manufacturers, different implant designs (screw cups) and surfaces, instruments (use of slide hammer), different surgical accesses and different patient positioning. Especially, the differences in the lesion frequency in gloves of the subordinate hand from operations at BuL can be explained by local factors. For example, one of the surgeons in BuL claims to use both hands equally, and after a fracture during childhood, a shortening of a finger occurred with the glove not fitting properly in that area. The influence of the design of the implantation instruments on the perforation rate of surgical gloves has not yet been investigated. Only a few studies are available on sutures [24].

In contrast, fewer lesions were found during arthroscopic procedures, which can be explained by the missing of lesions-risk such as open-rotating instruments (reamers, drills) [25]. In this study, the middle finger and thumb area were significantly more often affected. In the literature, the damage in arthroscopy is mainly attributed to the index finger $[24,26]$. The discrepancy in results may be due to different knotting techniques used by surgeons and suture materials from different manufacturers. In an in vitro experiment with various arthroscopic suture materials, lesions in the index finger area occurred more often [24]. However, the experimental set-up shown by Martinez et al. is missing resilient elements corresponding to the soft tissue structures of the patient. Dynamic saw-like movements of the suture material additionally damage the glove and, depending on the knotting technique, explains accumulated lesions to other parts of the glove.

\section{Glove leakage detection methods and the EN 455 standard}

To date, the water tightening test is the only required test to detect production associated leaks in gloves [6]. It is uncertain to what extent this test is suitable as the main detection method of glove injuries from the user's point of view. In the literature, it has been shown that this test is inaccurate, microperforations are insufficiently detected [24, 27]. Test methods using electrical conductivity (ECT) show a significantly better resolution, especially for micro-lesions [27]. Further test protocols should be implemented in the test procedures for tightness, as already established for other latex products [8], despite significantly higher cost pressure for surgical gloves. It is questionable whether sterile latex gloves produced under this standard are sufficiently safe for surgical use.

\section{Limitations of the study}

By lab-analyses, it was not possible to distinguish for each individual lesion whether it was caused initially by production process or during the operating procedure. No separate investigation was carried out for different producers and a distinction was made between latex and non-latex. Studies on translocation of bacteria through glove lesions were not performed. The influence on the postoperative wound infection rate as well as potential Infections of the staff were not examined.

\section{Conclusions}

Mechanical stress led to lesions on sterile surgical gloves. With increasing stress, the number of lesions increased. Depending on the performed operating procedure, differences in the location of the lesions on the gloves were 
observed. Standards for the intraoperative change of gloves should be established according to the type of intervention and should be documented in hygiene regulations. The CEN specifications do not yet cover the high mechanical intraoperative stress on gloves. Mechanical testing and special procedures for testing for micro-lesions should be introduced in addition to new glove materials and design.

Acknowledgements We would like to thank S. Zaatreh and T. König for the evaluations and analyses during the start of the project. We thank M. Jackszis for the technical support in the laboratory.

Author contributions $\mathrm{AE}, \mathrm{TK}, \mathrm{PW}, \mathrm{KOZ}, \mathrm{WM}$ and $\mathrm{AK}$ were responsible for data collection, analysis and interpretation of data, design of the work and revision. AE, TK, PW, KOZ, WM and AK approved the submitted version and agreed to be personally accountable for the author's own contributions and ensured that questions related to the accuracy or integrity of any part of the work, even ones in which the author was not personally involved, were appropriately investigated, resolved, and the resolution documented in the literature.

Funding This research received no specific grant from any funding agency in the public, commercial, or not-for-profit sectors. Open Access funding provided by Projekt DEAL.

\section{Compliance with ethical standards}

Conflict of interest A. Enz, T. Kostuj, P. Warnke, K. Osmanski-Ze$\mathrm{nk}, \mathrm{W}$. Mittelmeier and A. Klinder declare that there is no conflict of interest. $\mathrm{AE}$ is an honorary member of the standards committee NA 063-01-05AA (Medical disposable gloves) of the German Institute for Standardization (DIN). A. Enz stated that he had been reimbursed for overnight accommodation costs during a lecture at a symposium (1×RRC-Conqress GmbH Französische Str. 14-10117 Berlin).

Ethics approval and consent to participate Ethics approval for the study was granted by the local ethics committee of the Rostock University Medical Center (registration number: A2016-0112), data protection requirements were observed, consent to participate was not necessary.

Consent for publication All authors have given their consent to the publication.

Availability of data and materials The data were collected and evaluated within the Orthopedic clinic and polyclinic, University medicine Rostock Germany. The collected data obtained have been stored and are available at Orthopedic clinic and polyclinic.

Open Access This article is licensed under a Creative Commons Attribution 4.0 International License, which permits use, sharing, adaptation, distribution and reproduction in any medium or format, as long as you give appropriate credit to the original author(s) and the source, provide a link to the Creative Commons licence, and indicate if changes were made. The images or other third party material in this article are included in the article's Creative Commons licence, unless indicated otherwise in a credit line to the material. If material is not included in the article's Creative Commons licence and your intended use is not permitted by statutory regulation or exceeds the permitted use, you will need to obtain permission directly from the copyright holder. To view a copy of this licence, visit http://creativecommons.org/licenses/by/4.0/.

\section{References}

1. Kahveci Z, Selcen Kilinc-Balci F, Yorio PL (2019) Critical investigation of glove-gown interface barrier performance in simulated surgical settings. J Occup Environ Hyg 16:498-506. https://doi. org/10.1080/15459624.2019.1600702

2. Prevention of postoperative wound infections (2018) Recommendation of the German commission for hospital hygiene and infection prevention (KRINKO) at the Robert Koch Institute Prävention postoperativer Wundinfektioen. Bundesgesundheitsblatt-Gesundheitsforchung-Gesundheitsschutz 61:448-473. https ://doi.org/10.1007/s00103-018-2706-2

3. Quadlbauer S, Pezzei C, Jurkowitsch J et al (2019) Palmar angular stable plate fixation of nonunions and comminuted fractures of the scaphoid. Oper Orthop Traumatol 31:433-446. https:// doi.org/10.1007/s00064-019-00623-0

4. Sehmisch S, Lehmann W, Dreimann M et al (2019) Posterior vertebral column resection for correction of kyphotic deformity due to osteoporotic fractures of the thoracic spine. Oper Orthop Traumatol 31:311-320. https://doi.org/10.1007/s0006 4-019-0616-6

5. CEN-European Committee for Standardization (2001) CEN EN 455-1:2000 Medical gloves for single use-Part 1: Requirements and testing for freedom from holes

6. CEN-European Committee for Standardization (2019) CEN preEN 455-1:2019: Medical gloves for single use-Part 1: Requirements and testing for freedom from holes

7. CEN - European Committee for Standardization (2020) CEN EN455-1:2020-Medical gloves for single use-Part 1: Requirements and testing for freedom from holes

8. EN ISO 4074:2015 (2015) EN ISO 4074:2015-Natural rubber latex male condoms-Requirements and test methods (ISO 4074:2015)

9. Enz A, Klinder A, Mittelmeier H et al (2018) Damages with high consequences: analysis of perforations in surgical latex operation gloves from orthopedic surgeries. Eur J Microbiol Immunol (Bp) 8:159-162. https://doi.org/10.1556/1886.2018.00028

10. Zaatreh S, Enz A, Klinder A et al (2016) Prospective data collection and analysis of perforations and tears of latex surgical gloves during primary endoprosthetic surgeries. GMS Hyg Infect Control 11:Doc25. https://doi.org/10.3205/dgkh000285

11. Lipson ME, Deardon R, Switzer NJ et al (2018) Practice and attitudes regarding double gloving among staff surgeons and surgical trainees. Can J Surg 61:244-250

12. Battersby CLF, Battersby NJ, Hollyman M, Hunt JA (2016) Double-gloving impairs the quality of surgical knot tying: a randomised controlled trial. World J Surg 40:2598-2602. https://doi. org/10.1007/s00268-016-3577-z

13. Lee SW, Cho M-R, Lee H-H et al (2015) Perforation of surgical gloves during lower extremity fracture surgery and hip joint replacement surgery. Hip Pelvis 27:17-22. https://doi. org/10.5371/hp.2015.27.1.17

14. Partecke LI, Goerdt A-M, Langner I et al (2009) Incidence of microperforation for surgical gloves depends on duration of wear. Infect Control Hosp Epidemiol 30:409-414. https://doi. org/10.1086/597062

15. Al-Maiyah M, Bajwa A, Mackenney P et al (2005) Glove perforation and contamination in primary total hip arthroplasty. J Bone Joint Surg Br 87:556-559. https://doi. org/10.1302/0301-620X.87B4.15744

16. Harnoss J-C, Partecke L-I, Heidecke C-D et al (2010) Concentration of bacteria passing through puncture holes in surgical gloves. Am J Infect Control 38:154-158. https://doi.org/10.1016/j. ajic.2009.06.013 
17. Uçkay I, Harbarth S, Peter R et al (2010) Preventing surgical site infections. Expert Rev Anti Infect Ther 8:657-670. https://doi. org/10.1586/eri.10.41

18. Natsuhara KM, Shelton TJ, Meehan JP, Lum ZC (2018) Mortality during total hip periprosthetic joint infection. J Arthroplasty. https ://doi.org/10.1016/j.arth.2018.12.024

19. Lindeque B, Hartman Z, Noshchenko A, Cruse M (2014) Infection after primary total hip arthroplasty. Orthopedics 37:257-265. https://doi.org/10.3928/01477447-20140401-08

20. Laine T, Aarnio P (2004) Glove perforation in orthopaedic and trauma surgery. A comparison between single, double indicator gloving and double gloving with two regular gloves. J Bone Joint Surg Br 86:898-900. https://doi. org/10.1302/0301-620x.86b6.14821

21. Carter AH, Casper DS, Parvizi J, Austin MS (2012) A prospective analysis of glove perforation in primary and revision total hip and total knee arthroplasty. J Arthroplasty 27:1271-1275. https://doi. org/10.1016/j.arth.2012.01.021

22. Manjunath AP, Shepherd JH, Barton DPJ et al (2008) Glove perforations during open surgery for gynaecological malignancies. BJOG 115:1015-1019. https://doi.org/10.111 1/j.1471-0528.2008.01738.x

23. Yinusa W, Li YH, Chow W et al (2004) Glove punctures in orthopaedic surgery. Int Orthop 28:36-39. https://doi.org/10.1007/ s00264-003-0510-5
24. Martinez A, Han Y, Sardar ZM et al (2013) Risk of glove perforation with arthroscopic knot tying using different surgical gloves and high-tensile strength sutures. Arthroscopy 29:1552-1558. https://doi.org/10.1016/j.arthro.2013.05.022

25. Goldman AH, Haug E, Owen JR et al (2016) High risk of surgical glove perforation from surgical rotatory instruments. Clin Orthop Relat Res 474:2513-2517. https://doi.org/10.1007/s1199 9-016-4948-3

26. Kaplan KM, Gruson KI, Gorczynksi CT et al (2007) Glove tears during arthroscopic shoulder surgery using solid-core suture. Arthroscopy 23:51-56. https://doi.org/10.1016/j.arthr o.2006.10.012

27. Sohn RL, Murray MT, Franko A et al (2000) Detection of surgical glove integrity. Am Surg 66:302-306

Publisher's Note Springer Nature remains neutral with regard to jurisdictional claims in published maps and institutional affiliations. 